\title{
The Econometric Analysis of the Relation between the Current Accounts Deficit and the Budget Deficit of the Social Security Institution
}

\author{
Özgür Hakan ÇAVUŞ, Department of Recreation Management, Faculty of Tourism, Izmir Katip Celebi \\ University, Turkey; e-mail: ozgurhakan.cavus@ikc.edu.tr
}

\section{Cari İşlemler Açığı ile Sosyal Güvenlik Kurumu Bütçe Açığı Arasındaki İlişkinin Ekonometrik Analizi}

\begin{abstract}
This study examines the relation between the health expenditure and pension payments which are among the most important spending items leading to the budget deficit of the Social Security Institution (SGK) and the current accounts deficit, in other words the current deficit, which is one of the basic accounts of the balance of payments. For this purpose, the current deficit amounts obtained from the data of the Turkey Republic Central Bank between the years of 2002 and 2013 and the data on health expenditure and pension payments announced by SGK and included among the SGK budget deficit items were subject regression and correlation analyses with the SPSS 20.0 program. According to the results of the regression and correlation analysis, high level relation and explanation level were found between health spending and current deficit as well as between pension payments and current deficit. However, no econometric relation was found between current deficit and SGK budget deficit. Within the framework of the econometric analysis in our study, it was found that the current deficit increase had an effect of $72 \%$ on health spending and $75 \%$ on pension payments.
\end{abstract}

Keywords

JEL Classification Codes :
Current Deficit, Pension Payments, Health Spending, SGK Budget Deficits.

$$
\text { F32, H51, H55, H62. }
$$

\section{$\ddot{\mathbf{O z}}$}

$\mathrm{Bu}$ çalışmada, Sosyal Güvenlik Kurumunun (SGK) bütçe açığını oluşturan en önemli harcama kalemleri arasında yer alan sağlık harcamaları ve emekli aylığı ödemeleri ile ödemeler bilançosunun temel hesaplarından birisi olan cari işlemler açığı diğer bir deyişle cari açık üzerinde nasıl bir ilişki olduğu araştırılmıştır. Bu amaçla 2002-2013 yılları arasında Türkiye Cumhuriyeti Merkez Bankası (TCMB) verilerinden elde edilen cari açık miktarları ile SGK tarafından açıklanan ve SGK bütçe açığı kalemleri arasında yer alan sağlık harcamaları ve emekli aylığı ödemelerine ilişkin veriler SPSS 20.0 programı aracılığıyla regresyon ve korelasyon analizlerine tabi tutulmuştur. Regresyon ve korelasyon analizlerinin sonuçlarına göre sağlık harcamaları ve emekli aylığı ödemeleri ile cari açık arasında ayrı ayrı yüksek düzeyde ilişki ve açıklama düzeyi tespit edilmiştir. Ancak cari açık ile SGK bütçe açıkları arasında herhangi bir ekonometrik ilişki tespit edilememiştir. Çalışmamızda yapılan ekonometrik analizle çerçevesinde cari açık artışının sağlık harcamalarının 
üzerinde $\% 72$, emekli aylığı ödemelerinin üzerinde ise $\% 75$ oranında bir etkiye sahip olduğu belirlenmiştir.

\author{
Anahtar Sözcükler $\quad$ : Cari Açık, Emekli Aylığg Ödemeleri, Sağlık Harcamaları, SGK Bütçe \\ Açıkları.
}

\title{
1. Introduction
}

In the Turkish budget system, there is a direct and strong relation between public spending and the social protection spending covering much expenditure like education, health and pension payments. Therefore, the increase in public spending causes an increase in the current accounts deficit directly and/or by having positive impact on national income. The share of social protection spending in national income is quite high especially in social welfare states.

The most significant part of the SGK budget consists of the health spending and pension payments done by SGK among social protection spending. SGK premium incomes do not meet the SGK premium expenses in Turkey, except the last 2 or 3 year. This creates a budget deficit of SGK. This budget deficit is financed by the payments transferred by the budget of central administration.

The content and amounts of SGK health spending are determined by the Healthcare Implementation Communique. Among the health spending of SGK between 2002-2006, drug payments were on the top of the list which was replaced by the treatment expenditure from $2007 \mathrm{on}$. In addition to that, pension payments have a similarly significant and high share as well as the health payments. Health payments and pension payments by SGK cause budget deficit which is covered by public spending, thereby increasing the current deficit.

\section{Literature Review}

Balance of payments is a statistical document where values, transfer payments and reserve changes based on the economic flows among the locals and foreigners of an economy in a certain period are determined and recorded systematically and in accordance with the accountancy records (Karluk, 2011: 307; Seyidoğlu, 2013:327). Having a stable balance of payments, balances the current account balance with the balance of capital and finance account and therefore does not have a surplus or deficit in the balance of official reserves account (Ünsal, 2009:78). The basic accounts of the balance of payments are determined as current accounts, capital and finance account, net errors and omissions (Başkol, 2011:3). The current accounts is also known as current balance and constitutes the most important accounts group of the balance of payments providing accountancy of economic and financial relations between countries, that is the balance of foreign currency income and expenses of goods trade and producer factors of the reel sector of the economy. The current accounts consist of total of the balances for foreign trade (import-export 
balance), tourism income-expense balance, construction services, investment (net factor) incomes (foreign investment incomes and expenses) and current transfers (uncovered foreign receipts-uncovered foreign expenses) (Şahin, 2011: 48-49; Seyidoğlu, 2013: 328). Current accounts establish a direct link between the foreign economic relations of the country and its national income as it covers the import and export of goods and services produced in the current year. The goods manufactured in the country and sold to foreigners are a part of the Gross Domestic Product of the country. In outward economies, current accounts balance takes a significant part for the making of national income (Gross Domestic Product) (Seyidoğlu, 2013: 330).

The foreign trade deficit was considered as the most important cause of current deficit which became chronicle after the 2001 crisis in the Turkish economy had a parallel tendency with the current deficit taking the impacts of 2008 Global Crisis into consideration. Turkey had a fragile economy with respect to the share of current deficit in national income while the global crisis had a positive impact in this field. In the first years of the crisis, import had a higher decrease than export leading to a significant decrease in current deficit. A part of shrink in import was caused by the decline in energy prices and another part was caused by the inadequate economic activities (Y1lmaz, 2013: 243).

Public spending refers to spending for social order and security, national defence, education, transportation, environment and health which is the basic public spending items (Öztürk 2013: 120). The ratio of public spending/GDP referring to the share of public spending in GDP indicates the amount of resources used by the public sector, i.e. the size of public sector (Uzay, 2002: 152-53).

The increase in public spending causes an increase in current deficit directly and/or by having a positive effect on national income. However, the extent of increase in current deficit by public spending varies depending on the ratio of domestic and foreign public spending (Bayraktutan and Demirtaş, 2011: 13).

There is a direct and strong relation between public spending and social protection spending. In general, social protection is a system to provide social justice and income security while it is also accepted as a kind of insurance to prevent poverty. In addition, the social protection concept can be defined to cover the informal structure and market structures in addition to social security (Kapar, 2015: 185-187). Social protection are conveyed to the people in need through many mechanisms like unemployment benefits, pension payment, child support, housing benefit, national health insurance, vocational course programs (European Report on Development, 2010: 1-2 ; Kapar, 2005: 3-9). This type of spending in the Turkish budget system is expressed as social public spending or social protection spending (Özdemir, 2005).

If we look at the GDP ratio of social spending from the point of health spending and pension payment, we see that the health spending constitute the $3.2 \%$ of GDP in 2012 and $4,4 \%$ in 2013 while the pension payments constitute the $5.6 \%$ of GDP in 2002 and $8.2 \%$ 
Çavuş, Ö.H. (2016), “The Econometric Analysis of the Relation between the Current Accounts Deficit and the Budget Deficit of the Social Security Institution", Sosyoekonomi, Vol. 24(27), 211-224.

in 2013 (TÜİK, 2013). Among the social protection spending, the share allocated to pension payments is remarkably high.

Another item taking an important part of the social spending is the health spending. Today SGK has the power to directly influence the health policies and decisions on health services. This basic purchasing power of SGK is shaped by the SGK policies regarding repayment methods and amounts. Again, within the scope of the law no 5510 on the Social Insurances and General Health Insurances, the population covered in Turkey with respect to general health insurance and the scope of the health assurance package were kept quite wide. Within the scope of the assurance package, the amount of payment and the types of health services for payment by SGK are determined by the Health Implementation Communique which is amended quite often (Tatar, 2011: 129-130). Currently, it is expected to keep the drug and treatment expenditure, which takes the highest part among the health payments of SGK and new arrangements are made if this budget is exceeded. SGK uses the package price practice for certain services and payment per service practice for some other services (Akyürek, 2012: 147-150).

If we look at the classification of public health spending per institutions, we see that the $54 \%$ of the health spending in 2009 were made by SGK, 30\% by the institutions with general and mixed budget and $16 \%$ by the Ministry of Finance (TÜIK, 2013).

The fact that developing countries like ours transfer more share to drug spending among health expenditures than the industrialized countries emerges as a result of factors like more priority to therapeutic health services, foreign-source dependency in drug industry, increase of drug variety in the market due to rapid developments in technology and heavy use of antibiotics (P1nar, 2012: 60). Meanwhile, the drug payments of SGK were more than the treatment expenses until 2007 and turned other way round thereafter (Akyürek, 2012: 147-150). In addition, as of 2009, SGK happened to be the institution allocating more share to drug $(45,7 \%)$. This was followed by the Ministry of Finance who funded the health services of active public servants and their dependants as well as the green card holders. The share of drug in total spending is around $31,9 \%$. The reason of low share of drug spending among the expenditure of the Ministry of Health is the fact that the amounts of drugs consumed in the institutions of the Ministry of Health are paid by SGK or the Ministry of Finance to Ministry of Health. In average, the share of outpatient and inpatient treatment services in the total public health spending in 2009 was $63,6 \%$ while the same of drug spending was $29,9 \%$. These spending do not include resources transferred to the Ministry of Health (around 990 million TL for 2010) for out of pocket expenses, health spending by local administrations and primary care health services (TÜİK, 2009; Erol \& Özdemir, 2014: 28-31).

It became possible to meet the health care needs which couldn't be met before due to reasons like increase of use in health services, there are elements in the adopted repayment methods encouraging use of service, the expansion of service scope for the population groups with narrow scope of service (Green Card), expansion of service provider 
range for all population (public and private sector) and easy access to those who couldn't receive service due to various access obstacles and there was an increase both in the use of health services and in health spending (Çelik, 2011: 70-76).

SGK budget balance is related to the difference between the incomes and expenses of SGK. If SGK incomes are less than SGK expenses, there is a SGK budget deficit which is funded by the treasury payments transferred from the central administration budget. In 2002, the coverage ratio was $66.5 \%$ in 2002 and happened to be $89.2 \%$ in 2013 . The coverage ratio of SGK premium incomes for pension payments and health payments were $61 \%$ in 2002 and $70.2 \%$ in 2013. The budget transfers to social security institutions (SSK, Bağkur and Retirement Fund of Civil Servants) in the period of 1998-2007 increased 35 times and the budget transfers reached to $3.92 \%$ of GDP. It was noticed that the budget transfers to cover the funding deficit of SGK were substantially done for the insured people of SSK (4/a). The ratio of transfers from the central administration budget to close the SGK budget deficit to GDP was $2.76 \%$ in 2002 and $4.56 \%$ in 2013 (SGK, 2014).

\section{The Purpose, Scope and Constraint of the Study}

This study attempted to reveal by an econometric analysis whether there is a logic relation between current deficit and health spending, pension payments and SGK deficits from the budget of SGK. In this context, the years of economic crises were excluded to ensure more contribution by the results of data used in the study to the accuracy of results. In other words, the research data don't include the year or years with price instability like any devaluation, revaluation, stagflation and recession. Therefore, the study doesn't include the data on current deficit announced by TCMB (Turkey Republic Central Bank) between 2002-2013 and the data on SGK deficits, health spending and pension payments announced by SGK.

\section{Research Method and Hypotheses}

Secondary data was used in the research. Secondary data consists of the figures related to the current deficit announced by the Central Bank for the years between 2002 and 2013. In addition, the data of the Central Bank was taken into consideration for exchange rates and the currency rate in the last day of the last month of the current year was used. In addition, whole of the data related to SGK deficits, health spending and pension payments involved the data of the years between 2002 and 2013 announced by SGK under the headings of financial statistics. In this context, all data used in the study were visualized by tables and graphics. Finally the data was subjected to regression and correlation analysis.

\begin{tabular}{ll}
\hline Data set used and years & 12 years (2002-2013) \\
Analysis method used & Regression and Correlation Analysis \\
Dependent Variable & Current Deficit \\
Independent Variable & SGK Deficits \\
& Health Spending and Pension Payments \\
\hline
\end{tabular}


Çavuş, Ö.H. (2016), “The Econometric Analysis of the Relation between the Current Accounts Deficit and the Budget Deficit of the Social Security Institution", Sosyoekonomi, Vol. 24(27), 211-224.

Hypothesis 1: Current Deficit - SGK Deficits

$\mathrm{H}_{0}=$ There is no significant relation between current deficit and SGK Deficits.

$\mathrm{H}_{\mathrm{A}}=$ There is significant relation between current deficit and SGK Deficits.

Hypothesis 2: Current Deficit - Health Spending

$\mathrm{H}_{0}=$ There is no significant relation between current deficit and health spending.

$\mathrm{H}_{\mathrm{A}}=$ There is significant relation between current deficit and health spending.

Hypothesis 3: Current Deficit - Pension Payments

$\mathrm{H}_{0}=$ There is no significant relation between current deficit and pension payments

$\mathrm{H}_{\mathrm{A}}=$ There is significant relation between current deficit and pension payments.

\section{Research Findings and Evaluation}

Table 1 includes the data obtained from the research. The findings and evaluations based on this data are given with the tables. In this context, the study includes the data on current deficit, health spending, pension payment and SGK deficits with respect to the period between 2002 and 2013. In addition, the data was subjected to a regression and correlation analysis to reveal the findings on the effect created by health spending, pension payments and SGK deficits on current deficit (million TL).

Table: 1

Current Accounts, Health Spending, Pension Payments and SGK deficits per Years (2002-2013)

\begin{tabular}{|c|c|c|c|c|c|c|}
\hline Years & $\begin{array}{c}\text { Current Deficit } \\
\text { Million \$ }\end{array}$ & $\begin{array}{c}\text { \$ } \\
\text { Currency }\end{array}$ & $\begin{array}{c}\text { Current Deficit } \\
\text { Million TL }\end{array}$ & $\begin{array}{c}\text { Health } \\
\text { Spending }\end{array}$ & $\begin{array}{c}\text { Pension } \\
\text { Payments }\end{array}$ & $\begin{array}{c}\text { SGK } \\
\text { Deficits }\end{array}$ \\
\hline $\mathbf{2 0 0 2}$ & 626 USD & $1,6476 \mathrm{TL}$ & $1.031,40 \mathrm{TL}$ & $7.630,00 \mathrm{TL}$ & $16.687,00 \mathrm{TL}$ & $7.965,00 \mathrm{TL}$ \\
\hline $\mathbf{2 0 0 3}$ & $7.515 \mathrm{USD}$ & $1,3999 \mathrm{TL}$ & $10.520,25 \mathrm{TL}$ & $10.663,00 \mathrm{TL}$ & $25.174,00 \mathrm{TL}$ & $13.420,00 \mathrm{TL}$ \\
\hline $\mathbf{2 0 0 4}$ & $14.431 \mathrm{USD}$ & $1,3427 \mathrm{TL}$ & $19.376,50 \mathrm{TL}$ & $13.150,00 \mathrm{TL}$ & $30.661,00 \mathrm{TL}$ & $15.932,00 \mathrm{TL}$ \\
\hline $\mathbf{2 0 0 5}$ & $22.198 \mathrm{USD}$ & $1,3483 \mathrm{TL}$ & $29.929,56 \mathrm{TL}$ & $13.608,00 \mathrm{TL}$ & $38.537,00 \mathrm{TL}$ & $18.962,00 \mathrm{TL}$ \\
\hline $\mathbf{2 0 0 6}$ & $32.193 \mathrm{USD}$ & $1,4124 \mathrm{TL}$ & $45.469,39 \mathrm{TL}$ & $17.667,00 \mathrm{TL}$ & $45.076,00 \mathrm{TL}$ & $18.037,00 \mathrm{TL}$ \\
\hline $\mathbf{2 0 0 7}$ & $38.311 \mathrm{USD}$ & $1,1649 \mathrm{TL}$ & $44.628,48 \mathrm{TL}$ & $19.984,00 \mathrm{TL}$ & $52.312,00 \mathrm{TL}$ & $25.040,00 \mathrm{TL}$ \\
\hline $\mathbf{2 0 0 8}$ & $41.946 \mathrm{USD}$ & $1,5291 \mathrm{TL}$ & $64.139,63 \mathrm{TL}$ & $25.347,00 \mathrm{TL}$ & $59.137,00 \mathrm{TL}$ & $25.902,00 \mathrm{TL}$ \\
\hline $\mathbf{2 0 0 9}$ & $14.297 \mathrm{USD}$ & $1,4945 \mathrm{TL}$ & $21.366,87 \mathrm{TL}$ & $28.811,00 \mathrm{TL}$ & $68.604,00 \mathrm{TL}$ & $28.703,00 \mathrm{TL}$ \\
\hline $\mathbf{2 0 1 0}$ & 46.643 USD & $1,5450 \mathrm{TL}$ & $72.063,44 \mathrm{TL}$ & $32.509,00 \mathrm{TL}$ & $78.598,00 \mathrm{TL}$ & $26.714,00 \mathrm{TL}$ \\
\hline $\mathbf{2 0 1 1}$ & $77.089 \mathrm{USD}$ & $1,8980 \mathrm{TL}$ & $146.314,92 \mathrm{TL}$ & $36.500,00 \mathrm{TL}$ & $91.615,00 \mathrm{TL}$ & $16.235,00 \mathrm{TL}$ \\
\hline $\mathbf{2 0 1 2}$ & 48.867 USD & $1,7862 \mathrm{TL}$ & $87.286,24 \mathrm{TL}$ & $44.111,00 \mathrm{TL}$ & $105.294,00 \mathrm{TL}$ & $17.295,00 \mathrm{TL}$ \\
\hline $\mathbf{2 0 1 3}$ & $64.600 \mathrm{USD}$ & $2,1340 \mathrm{TL}$ & $137.856,40 \mathrm{TL}$ & $49.889,00 \mathrm{TL}$ & $119.162,00 \mathrm{TL}$ & $19.675,00 \mathrm{TL}$ \\
\hline
\end{tabular}

Source: TCMB Payment Balance Statistics, SGK Monthly Statistic Bulletins (social assistance increase is included in the pension payments, while additional payment is not. Health spending don 't include travel expenses) 
As shown in Table 1, current deficit in Turkey has a general trend of increase. In 2013, current deficit was reduced in foreign currency but following the increase in exchange rates, current deficit also increased in TL. The devaluation after 2001 caused a high increase in the currency. Therefore TL lost value against dollar and reached the level of 2011 back in 2002. In this context, currency increase always took place. In health spending, there was an increase between 2002 and 2013. In addition, pension payments and SGK deficits increased the same way. However, it can be said that there were significant reductions in SGK deficits between 2011-2013.

\section{Graph: 1}

\section{Current Accounts, Health Spending, Pension Payments, SGK Deficits}

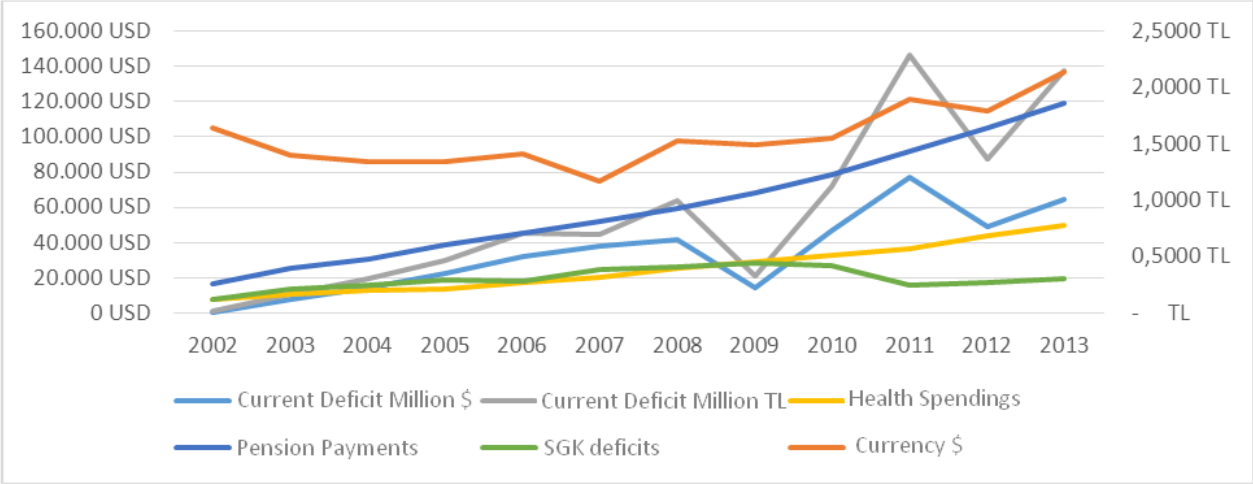

Foreign capital for new foreign investment in Turkey is very limited. In this sense, the current deficit continues at the expense of an increase in potential costs and risks. How heavy is the current deficit costs varies depending on the currency earning possibilities of the country and the way of funding this current deficit (Eren, 2011: 62-64). Many countries including Turkey fund current deficit by foreign currency. As shown in Graph 1, the current deficit in Turkey is in regular increase. SGK deficit took place as $146.314,92$ million TL in 2011, 87.286,24 million TL in 2012 and 137.856,40 million TL in 2013.

Current deficit was lowered with the 2008 global crisis after the 2001 crisis. When evaluated according to the Table 1, the economy with a current surplus of 3,7 billion in the 2001 crisis started to have current deficit again together with the recovery from crisis. The current deficit was around 7,5 billion dollars in 2003 while it increased to 38,3 billion dollars in 2007 and 41,9 billion dollars in 2008. Current deficit was slowed down with the effect of economic shrinkage in 2009 and happened to the 14,1 billion dollars while it continued to increase as of 2010 together with the recovery process after crisis. 
Before the years of economic crisis, exceeding the 4-5\% threshold values of the current deficit/GDP ratio as specified in the literature ${ }^{1}$ was considered as a signal of a possible economic crisis. This ratio was increased to $4,5 \%$ in 2005 with the effect of global crisis in parallel to the increase of current deficit while it was 1,9\% after 2001. As of 2010, the ratio of current deficit to GDP was $6,5 \%$ and reached to the highest level by increasing to $10 \%$. In 2012, the ratio of current deficit to GDP was reduced to $6,2 \%$ while still being much more than the critical threshold.

\section{Regression and Corelation Analyses}

Regression analysis is a method allowing a cause and effect relation between variables. Multiple regression analysis is used to analyse the relation between an independent variable and several independent variables (Gegez, 2010: 284-287; Nakip, 2010: 332; Kalayc1, 2010: 199). Correlation analysis is a technique of statistics determining whether there is a significant relation between two variables. In another words, the correlation analysis aims at measuring the power and direction of the relation between variables (Gegez, 2010: 284; Kalayc1, 2010: 115). This analysis reveals the linear relations while it may not be significant in a non-linear relation (Nakip, 2006: 342).

Table: 2

Multiple Regression Analysis Findings for the Current Deficit Increase

\begin{tabular}{|c|c|c|c|c|c|c|c|c|c|}
\hline $\begin{array}{l}\text { Independent } \\
\text { Variable }\end{array}$ & B & $\boldsymbol{\beta}$ & $t$ value & $\begin{array}{c}\text { Significance of } \\
t \text { value }\end{array}$ & $\begin{array}{c}\text { Corrected } \\
\mathbf{R}^{2}\end{array}$ & $\mathbf{R}^{2}$ & $\begin{array}{c}\mathbf{F} \\
\text { (Anova) }\end{array}$ & p. & D-W \\
\hline Fixed & 1442,604 &,- 228 & ,066 & ,949 & \multirow{4}{*}{ 797 } & \multirow{4}{*}{, 852} & \multirow{4}{*}{15,404} & \multirow{4}{*}{,001 } & \multirow{4}{*}{3,077} \\
\hline SGK Deficits & $-1,768$ &,- 228 & $-1,541$ & ,162 & & & & & \\
\hline Health Spending & $-9,075$ & $-2,611$ & $-1,513$ & ,169 & & & & & \\
\hline Pension payments & 5,196 & 3,569 & 2,060 & 073 & & & & & \\
\hline
\end{tabular}

As shown in Table 2, the explanation level of the independent variable for the dependent variable is statistically significant (corrected $R^{2}=0,797 ; \quad F=15,404$; $\mathrm{p}=0,001<0,005)$. In another words, the value in the significance column of the $\mathrm{F}$ (Anova) table indicates that the relation between the said variables is statistically significant at $\mathrm{p}<0,01$. After that the variables may be evaluated. F value 15,404 shows that the model with the level of 0,001 is valid as a whole and the three independent variables explain $79,7 \%$ of the changes in the dependent variable. Independent variables show that values of the coefficients for SGK deficits, health spending and pension payments are not valid at 0,05

1 One of the criteria that is widely used in determining the sustainability of current deficits is the $5 \%$ rule. According to this rule, it is accepted as a serious problem if current deficits exceeding $5 \%$ of GDP are financed by short term capital flows or international reserves and therefore the concerned deficits need to be followed closely (Edwards, 2001:13). It is considered as an economic risk if the ratio of current deficit to national income of a country becomes equal to or higher than 5\% (Freund and Warnock, 2005: 9). 
significance levels and their coefficients are not significant. Therefore, one needs to make correlation analysis between variables and remove from the model the insignificant independent coefficients with strong correlation. Durbin-Watson (D-W) coefficient is used to test autocorrelation. The value varies between 0 and 4 . Values near to 0 indicate excessive positive correlation, values near to 4 indicate excessive negative correlation and values near 2 indicate no autocorrelation. Therefore, it is desired to have the Durbing-Watson value between 1,5-25 (Kalayc1,2010: 264). In this context, the Durbin-Watson (D-W=3,077) value between the values is not at an acceptable level and excessive negative correlation was determined.

Table: 3

\section{Correlation Analysis for Interdimensional Relations}

\begin{tabular}{|l|l|c|c|c|c|}
\hline \multicolumn{2}{|c|}{ Dimensions } & $\mathbf{1}$ & $\mathbf{2}$ & $\mathbf{3}$ & $\mathbf{4}$ \\
\hline \multirow{3}{*}{ Current Deficit } & Pearson Correlation & &, 160 &, $864^{* *}$ &, $881^{* * *}$ \\
& Sig. (2-tailed) & $\mathbf{1}$ &, 620 &, 000 &, 000 \\
& $\mathrm{~N}$ & & 12 & 12 & 12 \\
\hline \multirow{3}{*}{ SGK Deficit } & Pearson Correlation &, 160 & &, 366 &, 376 \\
& Sig. (2-tailed) &, 620 & 1 &, 242 &, 228 \\
& $\mathrm{~N}$ & 12 & & 12 & 12 \\
\hline \multirow{3}{*}{ Health Spending } & Pearson Correlation &, $864^{* *}$ &, 366 & &, $997 * *$ \\
& Sig. (2-tailed) &, 000 &, 242 & $\mathbf{1}$ &, 000 \\
& $\mathrm{~N}$ & 12 & 12 & & 12 \\
\hline \multirow{3}{*}{ Pension Payments } & Pearson Correlation &, $881^{* * *}$ &, 376 &, $997^{* * *}$ & \\
& Sig. (2-tailed) &, 000 &, 228 &, 000 & $\mathbf{1}$ \\
& $\mathrm{N}$ & 12 & 12 & 12 & \\
\hline
\end{tabular}

**significant according to 0,01, * significant according to 0,05

As seen in Table 3, there is no significant relation between current deficit and SGK deficit $(r=, 160 ; p=0,620>0,05)$. In addition, there is a relatively strong and positive relation between the current deficit and health spending (Gegez, 2010: 278; Nakip, 2006: 343; Kalayc1, 2010: 116) $(\mathrm{r}=, 864 ; \mathrm{p}=0,000<0,05)$. In addition, there is a strong and positive relation between the current deficit and pension payments (Gegez, 2010: 278; Nakip, 2006: 343; Kalayc1, 2010: 116) $(\mathrm{r}=, 881 ; \mathrm{p}=0,000<0,05)$. That means, the inclusion of SGK deficits in the model made the other significant independent variables invalid. Therefore, when establishing a multiple variable regression model, it is useful to look at the correlation coefficients between the independent variables. It is necessary to remove insignificant independent variables from the model with strong correlation.

Table: 4

Regression Analysis Findings for the Current Deficit Increase

\begin{tabular}{|l|c|c|c|c|c|c|c|c|c|}
\hline $\begin{array}{l}\text { Independent } \\
\text { Variable }\end{array}$ & $\mathbf{B}$ & $\boldsymbol{\beta}$ & $\begin{array}{c}\mathbf{T} \\
\text { value }\end{array}$ & $\begin{array}{c}\text { Significance of } \\
\mathbf{t} \text { value }\end{array}$ & $\begin{array}{c}\text { Corrected } \\
\mathbf{R}^{\mathbf{2}}\end{array}$ & $\mathbf{R}^{\mathbf{2}}$ & $\begin{array}{c}\mathbf{F} \\
\text { (Anova) }\end{array}$ & $\mathbf{p .}$ & $\mathbf{D}-\mathbf{W}$ \\
\cline { 1 - 8 } Fixed & 32490,523 & - &, 658 &, 525 &,- 072 &, 025 &, 261 &, 620 &, 801 \\
\hline SGK Deficits & 1,240 &, 160 &, 511 &, 620 & &, 20 \\
\hline
\end{tabular}


As shown in Table 4, the explanation level of the independent variable for the dependent variable is not statistically significant (Corrected $R^{2}=-0,720 ; \quad F=, 261$; $\mathrm{p}=, 620>0,005)$. The SGK deficits used as independent variable don't make any effect on current deficit.

Table: 5

Correlation Analysis for the Interdimensional Relations (Current Deficit-SGK Spending)

\begin{tabular}{|l|l|c|c|}
\hline \multicolumn{2}{|l|}{ Dimension } & $\mathbf{1}$ & $\mathbf{2}$ \\
\hline \multirow{3}{*}{ Current Deficit } & Pearson Correlation & &, 160 \\
& Sig. (2-tailed) & $\mathbf{1}$ &, 620 \\
& $\mathrm{~N}$ & & 12 \\
\hline \multirow{3}{*}{ SGK Deficits } & Pearson Correlation &, 160 & \\
& Sig. (2-tailed) &, 620 & $\mathbf{1}$ \\
\hline & $\mathrm{N}$ & 12 & \\
\hline
\end{tabular}

**significant according to 0,01, * significant according to 0,05

As shown in Table 5, there is no significant relation between current deficit and SGK deficits $(r=, 160 ; p=0,620>0,05)$.

Table: 6

Regression Analysis Findings (Current Deficit-Health Spending)

\begin{tabular}{|l|c|c|c|c|c|c|c|c|c|}
\hline $\begin{array}{l}\text { Independent } \\
\text { variable }\end{array}$ & $\mathbf{B}$ & $\boldsymbol{\beta}$ & $\mathbf{t}$ value & $\begin{array}{c}\text { Significance of } \\
\mathbf{t} \text { value }\end{array}$ & $\begin{array}{c}\text { Corrected } \\
\mathbf{R}^{\mathbf{2}}\end{array}$ & $\mathbf{R}^{\mathbf{2}}$ & $\begin{array}{c}\mathbf{F} \\
\text { (Anova) }\end{array}$ & $\mathbf{p .}$ & $\mathbf{D}-\mathbf{W}$ \\
\cline { 1 - 8 } Fixed & $-18356,022$ & - & $-1,175$ &, 267 & \multirow{2}{*}{, 720} &, 746 & 29,340 &, 000 & 2,5 \\
\hline Health Spending & 3,002 &, 864 & 5,417 & 0,000 & 200 \\
\hline
\end{tabular}

As shown in Table 6, the explanation level of independent variable for dependent variable is statistically significant (Corrected $\mathrm{R}^{2}=0,720 ; \mathrm{F}=29,340 ; \mathrm{p}=0,000<0,005$ ). Accordingly, the explanation level of health spending used as independent variable $(\beta=, 864$; $\mathrm{t}=5,417 ; \mathrm{p}=0,000)$ for the dependent variable (current deficit) is statistically significant. The said dependent variable is explained by the independent variable by $72 \%$. In addition, the $\beta$ coefficient reveals the effect in dependent variable created by the one-unit increase in the independent variable. In this context, one unit increase in the independent variable causes an increase of 0,864 unit. The positive $\beta$ coefficient refers to a same direction relation between the variable and current deficit. In another words, current deficit will decrease when health spending go from 1 to 0 . It is important to have a coefficient of $B=3,002$ for health spending. This refers to an increase of three billion two million TL in the current deficit when the health spending has an increase of one billion TL. Durbin-Watson (D-W) coefficient is used to test autocorrelation. The value varies between 0 and 4 . Values near to 0 indicate excessive positive correlation, values near to 4 indicate excessive negative correlation and values near to 2 indicate no autocorrelation. Therefore, it is desired to have the Durbin-Watson value between 1,5-2,5 (Kalayc1, 2010: 264). It is seen that the DurbinWatson $(\mathrm{D}-\mathrm{W}=2,58)$ value between variables is at an acceptable level. 
Table: 7

Correlation Analysis for Interdimensional Relations (Current Deficit-Health Spending)

\begin{tabular}{|l|l|c|c|}
\hline \multicolumn{2}{|c|}{ Dimension } & $\mathbf{1}$ & $\mathbf{2}$ \\
\hline \multirow{3}{*}{ Current Deficit } & Pearson Correlation & &, $864 * *$ \\
& Sig. (2-tailed) & $\mathbf{1}$ &, 000 \\
& $\mathrm{~N}$ &, $864^{* *}$ & 12 \\
\hline \multirow{3}{*}{ Health Spending } & Pearson Correlation &, 000 & $\mathbf{1}$ \\
& Sig. (2-tailed) & 12 & \\
\hline
\end{tabular}

**significant according to 0,01, * significant according to 0,05

As shown by Table 7, we can say that there is a significant and very strong relation between current deficit and health spending $(r=, 864 ; p=0,000<0,01)$. In addition, the coefficients of both two independent variables are positive which indicates that the relation between the independent variables and dependent variables are in the same direction that is positive.

Table: 8

Regression Analysis Findings (Current Deficit-Pension Payments)

\begin{tabular}{|c|c|c|c|c|c|c|c|c|c|}
\hline $\begin{array}{l}\text { Independent } \\
\text { Variable }\end{array}$ & B & $\beta$ & $\begin{array}{c}\mathbf{T} \\
\text { value }\end{array}$ & $\begin{array}{l}\text { Significance of } \\
t \text { value (p) }\end{array}$ & $\begin{array}{c}\text { Corrected } \\
\mathbf{R}^{2}\end{array}$ & $\mathbf{R}^{2}$ & $\begin{array}{c}\mathbf{F} \\
\text { (Anova) }\end{array}$ & p. & D-W \\
\hline Fixed & $-21438,129$ & - & $-1,437$ & ,181 & \multirow{2}{*}{, 753} & \multirow[b]{2}{*}{,776 } & \multirow{2}{*}{34,592} & \multirow[b]{2}{*}{,000 } & \multirow[b]{2}{*}{2,703} \\
\hline Pension payments & 1,282 & 881 & 5,881 & 000 & & & & & \\
\hline
\end{tabular}

As shown in Table 8, the level of explanation of independent variable for dependent variable is statistically significant (Corrected $R^{2}=0,753 ; \quad F=34,592$; $\mathrm{p}=0,000<0,005)$. Accordingly, the explanation level of the pension payments which are used as independent variable for dependent variable (current deficit) is statistically significant. The said dependent variable is explained by the independent variable $75 \%$. In addition, the $\beta$ coefficient reveals the effect created by one unit increase in the dependent variable. In this context, it can be said that this one unit increase caused a 0,881 increase in the dependent variable. Having positive $\beta$ coefficient means that there is a positive relation. In other words, current deficit will reduce as pension payments move from 1 to 0 . It is also important to have 1,282 as the coefficient of pension payments. In this case, an increase of 1 billion TL in pension payments refers to one billion two hundred and eighty two million increase in current deficit. Durbin-Watson (D-W) coefficient is used to test the autocorrelation. The value changes between 0 and 4 . Values near to 0 indicate excessive positive correlation, values near to 4 indicate excessive negative correlation and values near 2 indicate no autocorrelation. Therefore, it is desired to have the Durbing-Watson value between 1,5-25 (Kalayc1, 2010: 264). In this context, the Durbin-Watson ( $D-W=2,70)$ value between the values is not at an acceptable level. 


\section{Table: 9}

\section{Correlation Analysis for Interdimensional Relations (Current Deficit-Pension} Payments)

\begin{tabular}{|l|l|c|c|}
\hline \multicolumn{2}{|c|}{ Dimensions } & $\mathbf{1}$ & $\mathbf{2}$ \\
\hline \multirow{3}{*}{ Current Deficit } & Pearson Correlation & &, $881^{* *}$ \\
& Sig. (2-tailed) & $\mathbf{1}$ &, 000 \\
& N & & 12 \\
\hline \multirow{3}{*}{ Pension Payments } & Pearson Correlation &, $881^{* *}$ &, 000 \\
12 & $\mathbf{1}$ \\
\hline & Sig. (2-tailed) & N & 12 \\
\hline
\end{tabular}

**significant according to 0,01, * significant according to 0,05

As shown by Table 9, it can be said that there is a significant and strong relation between current deficit and pension payments $(\mathrm{r}=, 870 ; \mathrm{p}=0,000<0,01)$. In addition, having positive coefficients of both independent variables indicates that the relation between independent variables and dependent variable is in the same direction that is positive.

\section{Conclusion and Discussion}

Table 1 indicates that the current deficit ratio in Turkey is in constant increase. In this context, the hypotheses, regression and correlation analyses were used to test the effect of SGK deficits, health spending and pension payments determined as independent variable on the current deficit figures determined as dependent variable. The data set which was analysed consists of statistical values declared by TCMB and SGK for the period of 20022013.

According to the findings of multiple regression analysis, explanation level of independent variables for dependent variable was found statistically significant (Corrected $\left.\mathrm{R}^{2}=0,797 ; \mathrm{F}=15,404 ; \mathrm{p}=0,001<0,005\right)$. However, as the coefficients of independent variables are not significant, first correlation analysis was made and the analysis continued by removing from the model the variable with no relation level in the model. Analysis was continued with the simple linear regression model. In other words, the relation of each independent variable and dependent variable was tested.

In addition, the most important constraint of the study is the fact the indicators for the period with price instability were not taken into consideration. Therefore, $\mathrm{H}_{0}$ hypothesis is accepted according to the Hypothesis 1 which was established before starting the study. In other words, no significant relation was found between the current deficit and SGK spending $(\mathrm{F}=0,261 ; \mathrm{p}=0,620>0,05)$. Accordingly, it can be said that SGK deficits didn't make any effect on current deficit.

However, in a study by Çıray (2014), it was found out that there was a significant relation $(\mathrm{r}=, 767 ; \mathrm{p}=0,000<0,01)$ between the $\mathrm{SGK}$ deficits, taken as dependent variable, and current deficit, taken as independent variable. In addition, the Current Deficit, which is 
independent variable in the same study, was found to explain $57 \%$ of the SGK deficits which are dependent variable. However, although the scientific studies put forward figurative relations, the subject needs to be grasped logically. Determining an item in the independent variable used in a study by Çıray (2014) provides a statistical judgement, however, the case is different.

The explanation level of health spending as another independent variable of the study for the dependent variable of current deficit is statistically significant. Accordingly, $72 \%$ (corrected $\mathrm{R}^{2}=, 720$ ) of the current deficit increase is caused by health spending. In addition, the correlation analysis found a significant and very strong relation between the two variables. Therefore $\mathrm{H}_{0}$ hypothesis is rejected and alternative hypothesis $\left(\mathrm{H}_{\mathrm{A}}\right)$ is accepted according to hypothesis 2 .

Finally, a statistically significant relation was found between the pension payments and current deficit. Accordingly, $75 \%$ of the current deficit increase is caused by pension payments. Therefore, $\mathrm{H}_{0}$ is rejected and $\mathrm{H}_{\mathrm{A}}$ is accepted in hypothesis 3 .

\section{References}

Akyürek, Ç. (2012), “Sağlıkta Bir Geri Ödeme Yöntemi Olarak Global Bütçe ve Türkiye”, Sosyal Güvenlik Dergisi, 2012/2, 124-153.

Başkol, O. (2011), “Cari açık ve Finansmanı”, Bursa Bilanço, No: 134, 1-7.

Çıray, U. (2014), "Sosyal Güvenlik Kurumu Açıkları İle Cari Açık Arasındaki İlişkinin Ekonometrik Analizi”, Sosyal Güvenlik Dünyası Dergisi, S. 90, 58-65.

Bayraktutan, Y \& İ. Demirtaş (2011), “Gelişmekte Olan Ülkelerde Cari Açı̆̆ın Belirleyicileri: Panel Veri Analizi”, Kocaeli Üniversitesi Sosyal Bilimler Fakültesi Dergisi, 2011/22, 13.

Edwards, S. (2001), “Does The Current Acount Matter?”, NBER Working Paper, No: 8275, 1-69.

Eren, A. (2011), Türkiye Ekonomisi, Ekin Kitabevi Yayınları, Bursa.

European Report on Development (2010), <http://www.erd-report.eu>, 01.12.2013.

Erol, H. \& A. Özdemir (2014), “Türkiye'de Sağlık Reformları ve Sağlık Harcamalarının Değerlendirilmesi”, Sosyal Güvenlik Dergisi, 2014/1.

Freund, C. \& F. Warnock (2005), "Current Account Deficit in Industrial Countries: The Bigger They Are, The Harder They Fall?", NBER Working Paper Series, No: 11823, 133-167.

Gegez, A.E. (2010), Pazarlama Araştırmaları, Beta Basım Yayım Dağıtım A.Ş, İstanbul.

Kalayc1, Ş. (2010), SPSS Uygulamalı Çok Değişkenli İstatistik Teknikleri, Öz Baran Ofset, Ankara

Kapar, R. (2005), Sosyal Korumanın İşgücü Piyasasına Etkisi, Birleşik Metal-İş Yayın No: 17/2005, İstanbul.

Kapar, R. (2015), “Uluslararası Çalışma Örgütü’nün Sosyal Koruma Tabanları Yaklaşımı”, Karatahta Iş̧ Yazıları Dergisi, Nisan 2015, S. 1, 181-209.

Karluk, S.R. (2011), Türkiye Ekonomisi, Anadolu Üniversitesi Yayınları, Eskişehir.

Nakip, M. (2006) Pazarlama Araştırmaları Teknikler ve (SPSS Destekli) Uygulamalar, Seçkin Yayınc1lık, Ankara. 
Özdemir, S. (2005), "Başlangıcından Günümüze Refah Devletlerinde Sosyal Harcamaların Analizi”, Sosyal Siyaset Konferansları Dergisi, N. 50, 153-204.

Öztürk, N. (2013), Kamu Maliyesi, Ekin Basım Yayın, Bursa.

Pınar, N. (2012) “Ülkemizde İlaç Harcamaları”, İnönü Üniversitesi Tıp Fakültesi Dergisi, 2012/19-1, $59-65$.

Seyidoğlu, H. (2013), Uluslararası İktisat Teori Politika ve Uygulama, Güzem Can Yayınları, İstanbul.

Sosyal Güvenlik Kurumu (SGK), 2002-2013 Yllları Aylık Sosyal Güvenlik Temel Göstergeleri, <http://www.sgk.gov.tr/wps/portal/tr/kurumsal/istatistikler/aylik_sosyal_guvenlik_temel _gostergeleri/>, 10.02.2015.

Sosyal Güvenlik Kurumu (SGK), 2002-2014 Yılları Arası Aylık Istatistik Bültenleri, <http://www.sgk.gov.tr/wps/portal/tr/kurumsal/istatistikler/aylik_istatistik_bilgileri>, 10.02.2015.

Şahin, B.E. (2011), “Türkiye'nin Cari Açık Sorunu”, Ekonomi Bilimleri Dergisi, C: 3/2, 47-56.

Tatar, M. (2011), "Sağlık Hizmetlerinin Finansman Modelleri: Sosyal Sağlık Sigortasının Türkiye’de Gelişimi”, Sosyal Güvenlik Dergisi, 2011/1, 103-133.

Türkiye Cumhuriyeti Merkez Bankası (TCMB), 2002-2013 Yılları Ödemeler Dengesi El Kitapları, <http://www.tcmb.gov.tr/wps/wcm/connect/30cdfd52-aa34-40ce-8b574ef53e322ce4/odemelerdengesi.pdf?MOD=AJPERES\&CACHEID=30cdfd52-aa3440ce-8b57-4ef53e322ce4>, 05.01.2015.

Türkiye İstatistik Kurumu (TÜİK) (2009), Hizmet Sunucularına Göre Sağlık Harcamalarl, <http://www.tuik.gov.tr/PreTablo.do?alt_id=1084>, 05.01.2015.

Türkiye İstatistik Kurumu (TÜİK) (2013), Kamu Kesimi Sosyal Harcama Ístatistikleri, <http://www.kalkinma.gov.tr/Pages/content.aspx?List=4fd56128-b7e9-440a-ad232eb59cd71e6a\&ID=7\&Source=http\%3A\%2F\%2Fwww\%2Ekalkinma\%2Egov\%2Etr\%2F Page>, 05.01.2015.

Uzay, N. (2002), "Kamu Büyüklüğü ve Ekonomik Büyüme Üzerindeki Etkileri: Türkiye Örneği (1970-1999)", Erciyes Üniversitesi İ̈BF Dergisi, S: 19, 151-172.

Ünsal, E.M. (2009), Makro İktisat, İmaj Yayınevi, Ankara.

Y1lmaz, B.E. (2013), "Küresel Krizin PIIGS (Portekiz, İrlanda, İtalya, Yunanistan ve İspanya) Ülkeleri ile Türkiye'nin Makroekonomik Değişkenlerine Yansımaları", Marmara Üniversitesi İktisadi ve İdari Bilimler Dergisi, C: 34/1, 229-252. 